\title{
BioéthiqueOnline
}

\section{A Pain in my Neck}

\section{Frank Verpaelst}

Volume 4, 2015

Reçu : 24 Feb 2015; publié : 31 Mar 2015; éditeurs : Stephen Clark \& Jean Poupart

URI : https://id.erudit.org/iderudit/1035497ar

DOI : https://doi.org/10.7202/1035497ar

Aller au sommaire du numéro

Éditeur(s)

BioéthiqueOnline

ISSN

1923-2799 (numérique)

Découvrir la revue

Citer cet article

Verpaelst, F. (2015). A Pain in my Neck. BioéthiqueOnline, 4.

https://doi.org/10.7202/1035497ar
Résumé de l'article

Je suis atteint de nanisme et je blogue principalement sur les questions liées au handicap. Cette oeuvre illustre une souffrance physique bien réelle, mais souvent invisible pour les autres.
Ce document est protégé par la loi sur le droit d'auteur. L'utilisation des services d'Érudit (y compris la reproduction) est assujettie à sa politique d'utilisation que vous pouvez consulter en ligne.

https://apropos.erudit.org/fr/usagers/politique-dutilisation/ 


\title{
A Pain in my Neck
}

\author{
TRAVAIL CRÉATIF / CREATIVE WORK \\ Frank Verpaelst ${ }^{1}$
}

Reçu/Received: 24 Feb 2015

Éditeurs/Editors: Stephen Clark \& Jean Poupart

Publié/Published: 31 Mar 2015

2015 F Verpaelst, Creative Commons Attribution 4.0 International License

Résumé

Je suis atteint de nanisme et je blogue principalement sur les questions liées au handicap. Cette oeuvre illustre une souffrance physique bien réelle, mais souvent invisible pour les autres.

\section{Mots clés}

nanisme, douleur, aquarelle

\section{Summary}

I have dwarfism and blog mainly about disability related issues. This work illustrates a real physical pain, often invisible to others.

\section{Keywords}

dwarfism, pain, watercolour

Affiliations des auteurs / Author Affiliations

${ }^{1}$ Montréal, Canada

\section{Correspondance / Correspondence}

Frank Verpaelst, frank_verpaelst@yahoo.com

\section{Conflit d'intérêts}

M. Verpaelst est un ami de Maude Laliberté, éditrice de section de BioéthiqueOnline; Mme Laliberté n'a pas été impliquée dans l'évaluation de ce manuscrit.

\section{Conflicts of Interest}

M. Verpaelst is a friend of Maude Laliberté, Section editor at BioéthiqueOnline; Ms Laliberté was not involved in the evaluation of this manuscript.

\section{Preamble}

I have dwarfism, and have been blogging (http://www.patreon.com/gutsydwarf), mainly about disability related issues and have been a guest several times now on various CBC radio shows.

\section{A Pain In My Neck}

There was a time when I used to paint abstract watercolours. I found it to be very relaxing, and it helped me to forget the pain my dwarfism causes in just about every joint of my body. Every once in a while, I noticed something familiar as I moved my brush: a shoulder here, a rib there. And so I would add some simple lines to enhance what I saw.

The process always mattered more to me than the end product: losing myself in the colours that appealed to me that day, randomly spreading them around, adding water here and there, tilting the page and letting my eye decide where the paint should flow.

For over ten years, almost no one except the closest of friends, and my wife, has ever seen these paintings, mostly due to my shyness. Also, I'm not a trained artist in any way, shape, or form. My doodles and paintings are simply an expression of what is inside of me, and not something I consider being for public consumption. With this painting that I call "Pain in My Neck", I make an exception, because I think it can serve as a reminder to us all to look beyond the surface, especially when we look at each other. 
A) Bioéthique

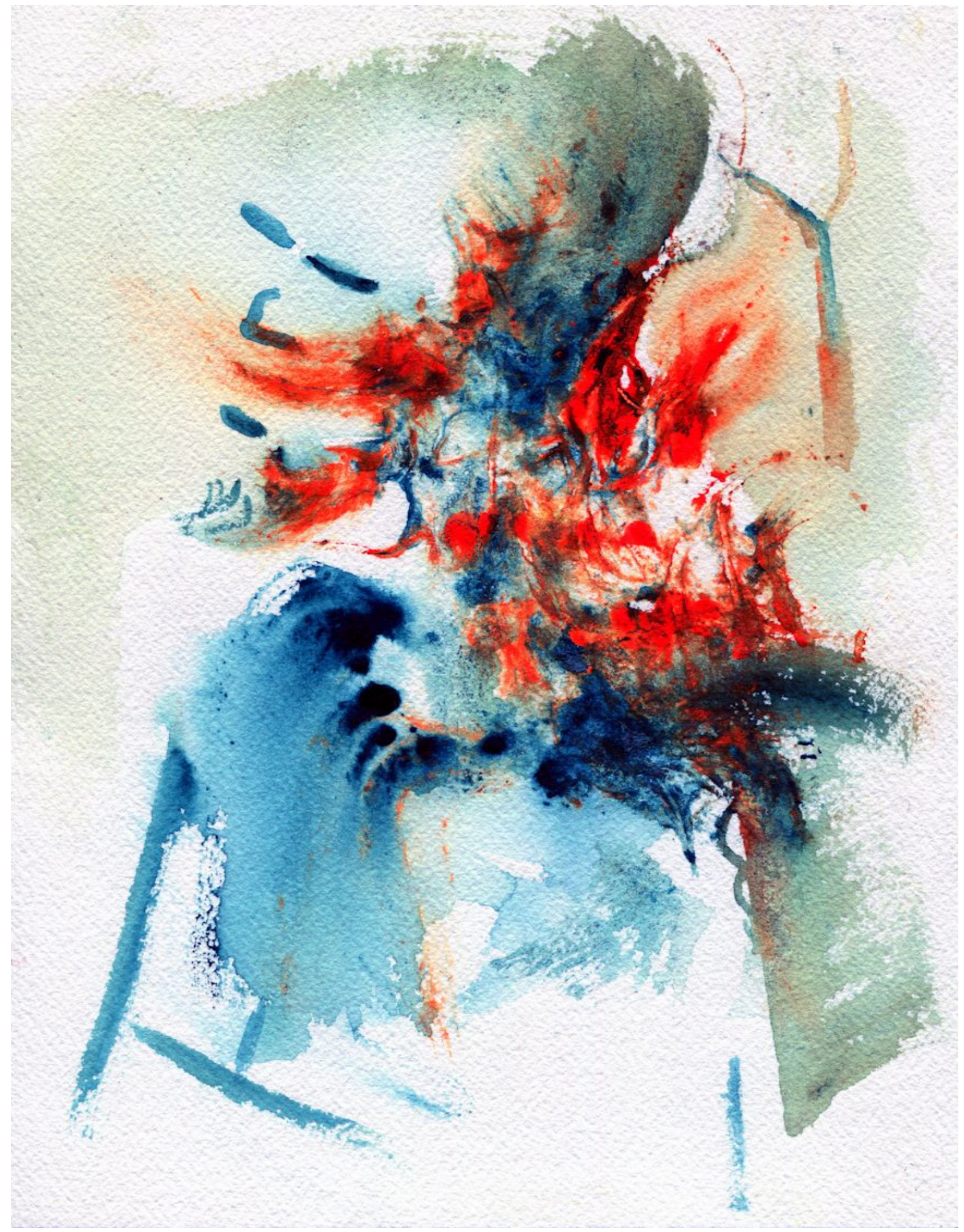


There was a time in my life I used to get a pinched nerve in my neck, about two or three times per year. Each time this happened, for several days, my neck felt like it was on fire, and I could hardly move it. Nothing but sleep would ease my suffering. And in the daytime, I hid that pain carefully from the world, hardly ever letting it show on my face.

I wish I was clever and skilled enough as an artist to say that this painting was intentional. But like all my abstract artwork, it is just one of the meditative things I do to shift my consciousness away from my body, and into a happier headspace, even if some of the end results appear to be of a dark or sad nature. I let my mind and hands wander, and then later, I reflect on the end results, to see what my subconscious might be trying to say.

Pain is somewhat like depression: many people experience it to a certain extent, and mostly on a temporary basis, but few understand the full impact when these things reach acute levels. Chronic and persistent pain, like depression, has a draining effect that bleeds the colour and joy from our lives.

As a person with a disability, one reason I hide my pain is because there are already enough visual reminders to the outside world that I'm not like most other people. I do not want to give society another reason to count me out, to exclude me, to say to themselves, "Oh, Frank can't do this certain activity, he has too much pain". So, instead of revealing my misery, I bury my pain, and push forward, pretending that all is well. I'm not saying it's the right thing to do, it is just how I handle things in my own life.

But the main reason I hide my pain is because I refuse to let it stop me from enjoying a full life. Pain after all is just a signal from my nerve endings that tells my brain something might be wrong in some part of my body. Having experienced pain for virtually my whole life, mostly due to osteoarthritis and seven orthopedic surgeries, I know there is nothing to be done except relax whenever possible, and take non-prescription pain killers when absolutely necessary.

Having shared this painting, and my thoughts about it with you, I simply ask that the next time you look at another person, remember that no matter their calm exterior, you actually have no clue the pain they may be feeling on the inside. This holds true for emotional and not just physical pain. As you interact with people, remember to treat each other with gentleness and kindness, and be the cooling soothing rain that can put out those painful fires wherever you go, instead of assuming people are okay. 